The Politics of Change in the Health Service 
Also by Brian Salter

Education and the Political Order

Education, Politics and the State

Power and Policy in Education

Oxford, Cambridge and the Idea of a University

The State and Higher Education

The Clinician's Management Handbook 


\title{
The Politics of Change in the Health Service
}

\author{
Brian Salter
}

MACMILLAN 
(C) Brian Salter 1998

Reprint of the original edition 1998

All rights reserved. No reproduction, copy or transmission of this publication may be made without written permission.

No paragraph of this publication may be reproduced, copied or transmitted save with written permission or in accordance with the provisions of the Copyright, Designs and Patents Act 1988, or under the terms of any licence permitting limited copying issued by the Licensing Agency, 90 Tottenham Court Road, London W1P 9HE.

Any person who does any unauthorised act in relation to this publication may be liable to criminal prosecution and civil claims for damages.

The author has asserted his rights to be identified as the author of this work in accordance with the Copyright, Designs and Patents Act 1988.

First published 1998 by MACMILLAN PRESS LTD

Houndmills, Basingstoke, Hampshire RG21 6XS

and London

Companies and representatives

throughout the world

ISBN 978-0-333-65641-9 ISBN 978-1-349-26224-3 (eBook)

DOI 10.1007/978-1-349-26224-3

A catalogue record for this book is available from the British Library.

This book is printed on paper suitable for recycling and made from fully managed and sustained forest sources.

$\begin{array}{llllllllll}10 & 9 & 8 & 7 & 6 & 5 & 4 & 3 & 2 & 1\end{array}$

$\begin{array}{llllllllll}07 & 06 & 05 & 04 & 03 & 02 & 01 & 00 & 99 & 98\end{array}$

Editing and origination by Aardvark Editorial, Mendham, Suffolk 
This book is dedicated to Medway NHS Trust 


\section{Contents}

Foreword ix

Introduction 1

1 The politics of change in the health service 4

Introduction 4

Review and reform 5

The political problem - citizenship, rights and welfare limits 11

Power and change in the Health Service 15

Conclusions 21

2 Purchasing 23

Introduction $\quad 23$

The context 24

The new political game 25

The political difficulties $\quad 37$

Conclusions $\quad 45$

3 Providing $\quad 5$

Introduction $\quad 50$

The management of demand 51

The web of accountability $\quad 57$

Inside the Trusts 65

$\begin{array}{ll}\text { Conclusions } & 72\end{array}$

4 Primary health care $\quad 75$

Introduction 75

Traditional demand management $\quad 76$

The reforms of primary health care $\quad 77$

The changing power structures 93

$\begin{array}{ll}\text { Conclusions } & 95\end{array}$ 
5 Medicine $\quad 98$

$\begin{array}{ll}\text { Introduction } & 98\end{array}$

Professional power and the pressures for change $\quad 98$

Training and accreditation 107

Career structure 116

Professional standards $\quad 122$

$\begin{array}{ll}\text { Conclusions } & 125\end{array}$

6 Nursing 129

Introduction $\quad 129$

$\begin{array}{ll}\text { Nursing and medicine } & 129\end{array}$

Practice innovations $\quad 135$

The policy challenge $\quad 139$

Conclusions 151

7 Community care $\quad 155$

Introduction $\quad 155$

Origins of the policy 156

Controlling demand 161

Protecting supply 168

Policy implementation $\quad 172$

$\begin{array}{ll}\text { Conclusions } & 181\end{array}$

8 The private sector $\quad 185$

Introduction $\quad 185$

Perspectives on the private sector and NHS relationship $\quad 186$

Defining the private sector and NHS relationship 192

Managing the private sector and NHS relationship 195

The Private Finance Initiative 201

Conclusions 206

9 Conclusions 209

Introduction 209

The problem of citizenship $\quad 209$

The balance of power $\quad 212$

$\begin{array}{ll}\text { Conclusions } & 221\end{array}$

References 223

Index 249 


\section{Foreword}

No-one who works in the National Health Service can be unaware of the political pressures which permeate its daily life. Widely regarded as the most successful institution of the welfare state, the NHS is expected by the general public and politicians alike to deliver an ever-increasing range of services within a budget which has never been able to cover all the demands that are made upon it. Increasingly and, quite rightly, these expectations make their presence felt through clearer systems of accountability and public scrutiny which leave little room for manoeuvre, exposing for public examination and debate the NHS's failure to meet expectations whether they be realistic or not. It has a heavy cross to bear.

In a sense (and highlighted by my association with the writing of this book), this should not be regarded as surprising. The NHS is a public organisation which has statutory duties to deliver health care to the British people. Insofar as they perceive that these duties are not being delivered, they will legitimately demand that their elected representatives press for changes to be made. Thus politics and the NHS are rightly inseparable.

It has always been the task of managers and professionals alike (although sometimes in very different ways), to reconcile these increasing and often mutually exclusive demands and it is much more easily said than done. Traditionally there has been little filtering of public demand on the NHS and prioritisation, whatever form it takes, brings ethical problems (sometimes) and political difficulties (always). What is more, the effect of recent policy initiatives, including the separation of purchaser and provider functions, the Patient's Charter and the Health of the Nation initiative, has been to provide new and powerful vehicles for focusing the demands on the NHS - both old and new.

The arrival of the contract culture, perhaps more than any other factor, has provided a potent mechanism for identifying the NHS's success and its failures. Its performance, converted dispassionately into Finished Consultant Episodes and the like, is graphically displayed with the burgeoning power of information technology for judgement at a glance. In its wake, many health professionals have been left scratching 
their heads. What happened to the quest for quality? Is it to be measured or distorted by the imperative to deliver demanding contract volumes? What scope for a 'real' quality service, they ask, when driving to meet volume targets and when preparing for the close attentions of an everwatchful media when the league tables are about to be published?

The main professional groups within the NHS are coming to terms with these changes in their own way. The doctors, it seems, having resisted the NHS reforms in their early years, are now 'getting on with the job'. For many this means a greater involvement with the nonclinical and the financial management of the service. General Practitioners have got to grips with Fundholding and many specialists have realised that the future of their trade in the NHS depends increasingly on their influence at least with the 'big purchasers' if not with all the little ones. After the early spats over the reforms it seems that the profession has accepted 'the new way' and the government and the NHS should be content with that.

For managers and for the nurses, some old and some new realities have had to be accepted. The managers have learned to wear 'the grey suit' and to recognise that while they will rarely be given credit for what the NHS achieves, they will frequently be the butt for all that goes wrong. That said, they are taking comfort from increasing recognition of their contribution from their professional colleagues and from a better informed public who know full well that large, complex and expensive organisations do not run themselves. For nurses, who remain the public's 'angels', there has been perhaps a more traumatic relegation of their status and influence at the top tables.

For both professions, it has become axiomatic that they must work within the dominance of medicine and that their objectives will rarely be achieved if they fly in the face of medical opinion. If the grey suits have few friends, if nurses remain the public's favourite, it is the medical profession's relationship with the government of the day that makes things happen - or not - in the NHS.

One of the key messages of this book is that all policy ambition must be set with reference to the reality of power structures and a recognition of the difference between rhetoric and practical possibility. In its development the work has engaged both managers and clinical professionals working in the Medway NHS Trust during a period of major transformation, with episodes of uncomfortable dialogue around the implementation of radical national policies and local structural change. Taking time out to contemplate the underlying power structures of the NHS 
does not fit easily with the pressures of daily life for managers and professionals in the NHS but is nevertheless an important aspect of their political development. This book provides powerful insights into these issues and they should not be ignored. To be oblivious to them is to stare through a glass busily but darkly, and with an increasing sense of frustration.

Ken Hesketh

Chief Executive, Medway NHS Trust 